Original paper UDC 28-14(045)

doi: $10.21464 / \mathrm{sp} 31213$

Received January $21^{\text {st }}, 2016$

\title{
Željko Paša
}

Saint Joseph University in Beirut, Centre for Documentation and Research of Arabic Christianity (CEDRAC), Rue de l'Université Saint-Joseph, B. P. 16-6778, Achrafieh, LB-1100 2150 Beirut zeljko.pasa@usj.edu.lb

\section{The Concept of God's Unity in

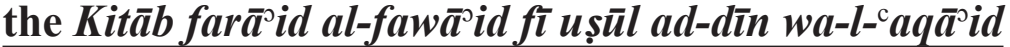 by ${ }^{\mathrm{c}} \mathbf{A} \underline{\mathrm{b}} \mathrm{d} \overline{\mathbf{s}} \bar{u}^{\mathrm{c}}$ bar Brīhāa}

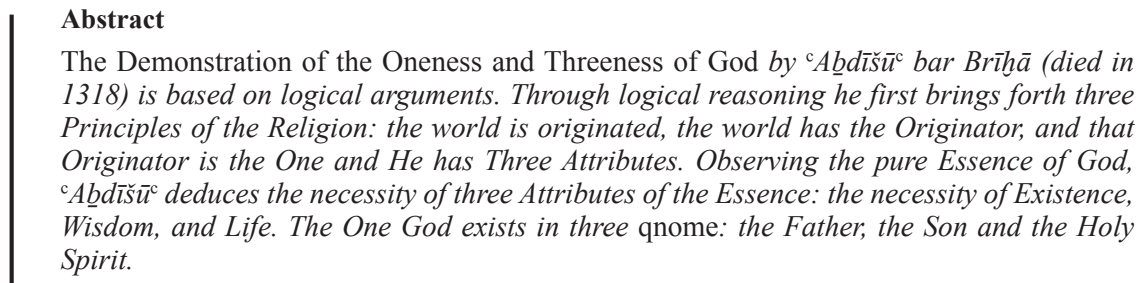

\section{Keywords}

Attributes, Essence, Trinity, Oneness, Threeness, Qnoma
}

\section{Introduction}

In the development of the Trinitarian dogma, the expression of God's Oneness in Threeness and Threeness in Oneness was a great challenge to the Church, involving many misconceptions, heresies and schisms, all with painful consequences. Once the Trinitarian dogma was established during the ecumenical councils of Nicaea (325) and Constantinople (381), with the adoption of the standardized terminological formula of the Cappadocian Fathers as $\mu$ í $\alpha$ ovं $1 \alpha$ - $\tau \rho \varepsilon 1 \varsigma$ i $\pi 0 \sigma \tau \alpha \dot{\sigma} \sigma \varepsilon \varsigma_{\zeta},{ }^{1}$ the Christians under the reign and shadow of the Crescent were exposed to new challenges. In confrontation with the rigorous monotheism of Islam and Islamic accusations of Christian polytheism, Arab Christian writers were required to defend God's Oneness in Threeness in a new cultural and reli-

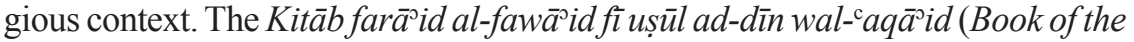
Pearls of Utility: On the Principles of the Religion and Dogmas) by ${ }^{\mathrm{C}} \mathrm{A} \underline{\mathrm{b}} \mathrm{d} \overline{\mathrm{s}} \bar{u}^{\mathrm{c}}{ }^{\mathrm{b}} \mathrm{bar}$ Brīhā, Metropolitan of Nisibis (died in 1318), is one example of the exposition of Christian teaching on the Trinity in a dialogue with Islam. He was Metropolitan of Nisibis, and he is the last of the great writers in the Church of the East.

${ }^{\mathrm{c} A} \mathrm{~b} \mathrm{~b} \overline{\mathrm{I}}_{\mathrm{is}} \overline{\mathrm{u}}^{\mathrm{c}}$ was a Syriac Renaissance man, a polymath (homo universalis) and a prolific writer, both in Syriac and in Arabic. With encyclopaedic knowl-

1

For development of the dogmatic formula $\mu$ í

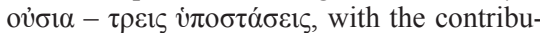
tion of the Cappadocian Fathers Basil the Great (330-379), Gregory of Nyssa (c. 332-
395), and Gregory of Nazianzus (329-389), see "La formula dogmatica 'mia ousia - treis hypostaseis",, in Studer, Dio salvatore, pp. 201-206. 
edge, he produced writings covering almost all domains of the humanistic disciplines: philosophy, theology, chronology, controversies, exegesis, canon law, and poetry. The theological tradition of the School of Antioch finds its synthesis, culmination and conclusion in ${ }^{\mathrm{c}} \mathrm{A} \underline{\mathrm{b}} \mathrm{d} \overline{\mathrm{i}} \overline{\mathrm{s}}^{\mathrm{u}} \mathrm{c}$. German Orientalist Peter Kawerau called him "der Abschluß der antiochenischen Theologie"2 (the conclusion of the Antiochian theology).

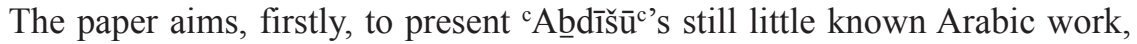
the Kitāb farā $\bar{a}^{\supset}$ al-faw $\bar{a}^{\supset} i d$; secondly, to expose its teaching on the Oneness of God; and, finally, to analyze its doctrine on the Threeness of God exposed in the dialogue with Islam.

\section{Presentation of the Kitāb far $\bar{a}^{\top} i d$ al-fawa $\bar{a}^{\curvearrowright} i d$}

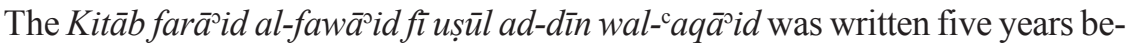
fore ${ }^{\mathrm{c}} \mathrm{A} \underline{b} d \overline{1} \overline{\mathrm{s}} \bar{u}^{\mathrm{c}}$ 's death. According to ${ }^{\mathrm{c}} \mathrm{A} \underline{b} d \overline{\mathrm{i}} \mathrm{s} \overline{\mathrm{u}}{ }^{\mathrm{c}}$ 's testimony, the book was written in 1313. On the occasion of the 700th anniversary of its composition, in 2013, its critical edition was presented at the Pontifical Oriental Institute in Rome. ${ }^{3}$

\subsection{Sources}

The Kitāb farā̃id al-fawā̃id has been preserved, till now, only in the following manuscripts:

1) Ms. Vat Ar. 110 is from the XIVth century, from 1320. The manuscript is in Arabic and Syriac. The manuscript is incomplete. It contains part of the introduction and chapters V, VI, and VII of the Kitā farāid al-faw $\bar{a}^{\top} i d$. In the critical edition, it is integrated from fol. $198 \mathrm{v}-207 \mathrm{v}$. The manuscript is preserved in the Biblioteca Apostolica Vaticana. ${ }^{4}$

2) Ms. Par Ar. 206 is from the XIVth century, from 1371. The manuscript, in Arabic, is less incomplete. It is missing the end of chapter VII and chapters VIII, IX, and X. In the critical edition it is integrated from fol. $12 \mathrm{v}-62 \mathrm{v}$. The manuscript is preserved in the Bibliothèque nationale de France in Paris. ${ }^{5}$

3) Ms. Berl. Syr. $116=$ Sachau 12 is from the XIVth century; the exact year is unknown. The manuscript, in Arabic and Syriac, is incomplete. It contains part of the introduction and chapters V, VI, and VII. In the critical edition it is integrated from fol. 210r-221r. The manuscript is preserved in the Staatsbibliothek in Berlin. ${ }^{6}$

4) Ms. Beirut Ar. 562 is from the XVIth century, from 1563. The manuscript, in Arabic and Syriac, is more or less comprehensive but incomplete. Some pages are bound in the wrong order and with the wrong pagination. A part of chapter IV is incorporated into chapter VI. The manuscript is missing the end of chapter IX and the beginning of chapter X of the Kitāa farā̃id $a l-f a w \bar{a}^{\wedge} i d$. In the critical edition it is integrated from fol. $15 \mathrm{v}-69 \mathrm{r}$. The manuscript is preserved in the Oriental Library of Beirut. ${ }^{7}$

5) Ms. Neofiti 54 is from the XVIIIth century; the exact year is unknown. The manuscript, in Arabic and Syriac, is incomplete. It contains part of the introduction and chapters V, VI, and VII of the Kitāb farā id al-faw $\bar{a}^{\top} i d$. In the critical edition it is integrated from fol. 158r-163r. The manuscript is preserved in the Vatican Library. ${ }^{8}$

6) Ms. Cambridge add. 2889 is from the XVIIIth century, written in the year 1730. The manuscript is in Garšuni, in Eastern Syriac script. It is incomplete. It contains a part of the introduction and chapters V, VI, and VII of 
the Kitāb far $\bar{a}^{\mathrm{T}} i d$ al-faw $\bar{a}^{\mathrm{T}} i d$. In the critical edition it is integrated from fol. $219 \mathrm{v}-227 \mathrm{v}$. The manuscript is preserved in the Library of the University of Cambridge. ${ }^{9}$

For the dating of the death of ${ }^{\mathrm{c}} \mathrm{A} \underline{b} \mathrm{~d}_{\overline{1}} \mathrm{u}^{\mathrm{c}} \mathrm{c}$ and for the confirmation of the origi-

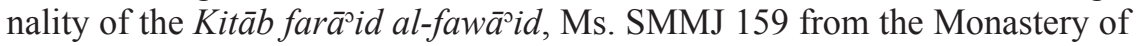
St. Mark in Jerusalem provided reliable evidence. The manuscript is in Syriac, written in the Eastern Syriac script. Some paragraphs are written in Arabic.

\section{The scheme of reconstruction}

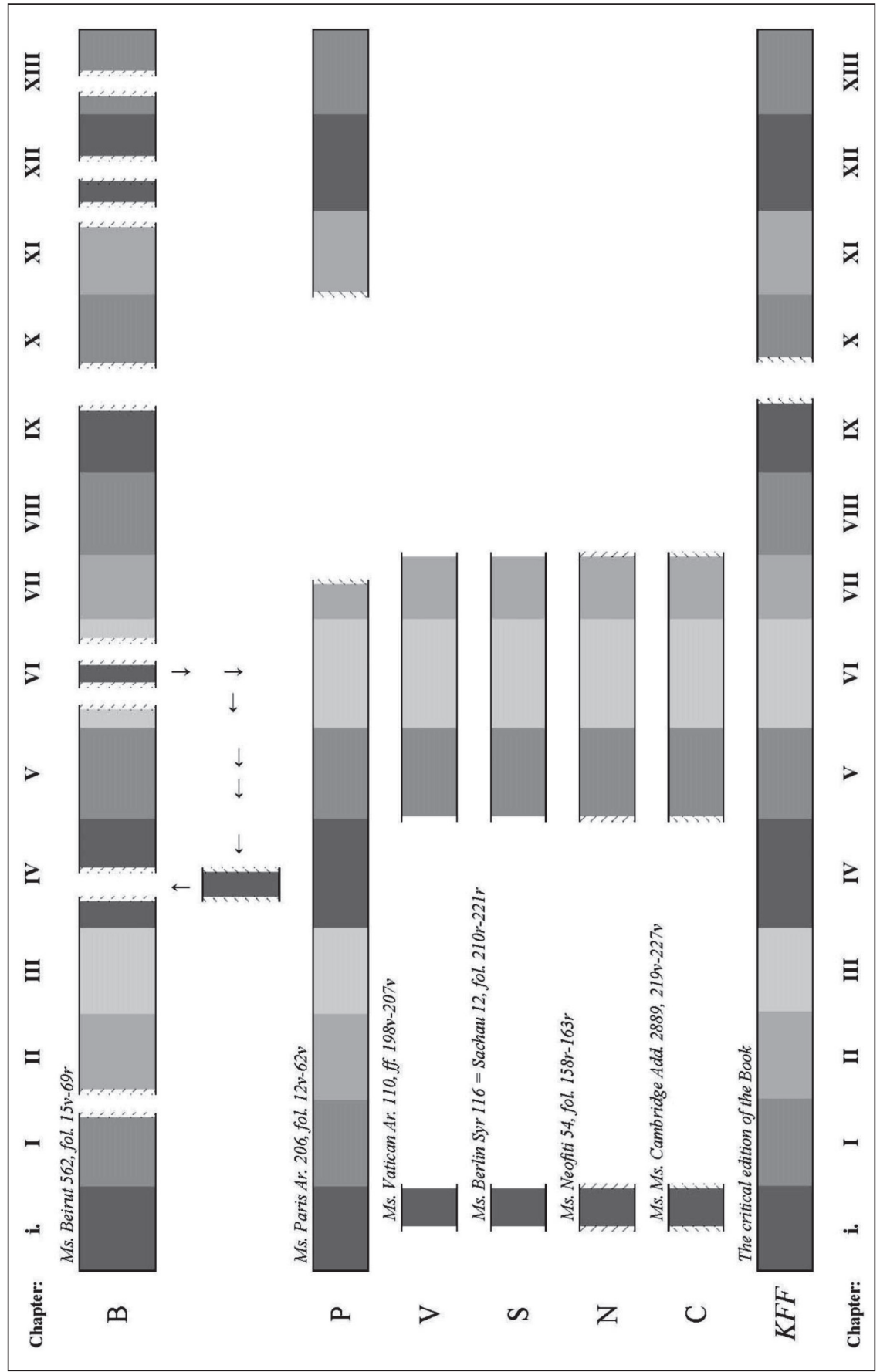




\subsection{Addressees}

The addressees of the Kitāb farāंid al-fawāoid are not noted. It is also not noted why ${ }^{\mathrm{c}} \mathrm{A} \underline{\mathrm{b}} \mathrm{d} \overline{\mathrm{i}} \overline{\mathrm{S}}^{\mathrm{u}}{ }^{\mathrm{c}}$ wrote in Arabic, while the official language of the Church of the East was Syriac and his contemporary patriarch, Yabhalāhā III (12811317), did not know Arabic because he was of Mongol roots. Although the Kitāa farāid al-fawāoid does not specify the identity of its addressees, their identity can be deduced from the content, tone, and style of the Book.

Moreover, the Kitāb far $\bar{a}^{\top} i d$ al-fawa $\bar{a}^{\top} i d$ imitates, in many places, the Qur'an and Qur'anic style. There are many expressions quoted from the Qur'an in order to confirm that Christianity is true while Islam is wrong. This can lead to conclusion that one of the addressees is the Muslim community.

Further, expressions such as the 'People of the Book' (Ahl al-kitāb) $(14,746$, $768 \mathrm{KFF}),{ }^{10}$ the 'People of the religion' ( $\mathrm{Ahl}$ ad-din) $(536 \mathrm{KFF})$, the 'Divine Books' (al-Kutub al-Ilahiyya) (127, 169, 397, 427 KFF), and the 'Descended Books' (al-Kutub al-Munzala) (746 KFF) occur in the text. These are all Muslim expressions and they refer to Jews, Christians, and Muslims, as the text once mentions: "all the legitimate Jews, Christians, and Muslims" (125 $K F F$ ).

In the introduction of the Kitāa far $\bar{a}^{\supset} i d$ al-faw $\bar{a}^{\supset} i d{ }^{\mathrm{c}} \mathrm{A} \underline{\mathrm{b}} \mathrm{d} \overline{\mathrm{s}} \mathrm{u}^{\mathrm{c}} \mathrm{c}$ polemicizes:

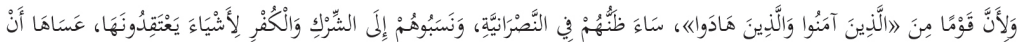

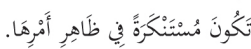

"And because [some] people [from among] 'those who believed and those who were Jews'11 have a bad suspicion about Christianity, and they ascribe to them [Christians] polytheism and rejection of the faith for the things they believe, which may be condemned for their external appearance." (20-22 KFF)

"Those" who "have a bad suspicion about Christianity" $(20$ KFF) and "named them [Christians] polytheist" $(21 K F F)$ are the same as "those who believe in God and the Last Day" (745 KFF) and who had the obligation of fasting, prayer and almsgiving imposed upon them by "their descended Books" (746 KFF). The "those" to whom "A $\underline{b} d \overline{1} \bar{s}^{\mathrm{u}} \bar{u}^{\mathrm{c}}$ refers can only be Jews and Muslims.

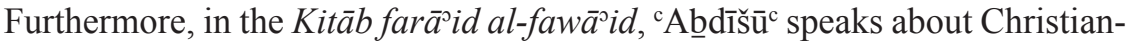
ity, Christians, their true belief (through exposition of their dogmas), and why they believe as they do, but he never specifies any Christian denomination. In the Ktaba d-Marganitha (Profession of the Faith) ${ }^{12}{ }^{\mathrm{c}} \mathrm{A} \underline{\mathrm{b}} \mathrm{d} \overline{\mathrm{s}} \mathrm{u}^{\mathrm{c}} \mathrm{c}$ specifies the Jacobites and Melkites and what they believe, as opposed to the Orientals (i.e. the Church of the East). ${ }^{13}$

In conclusion, regarding the addressees, it can be asserted that the Kitāb far $\bar{a}^{\top} i d$ al-faw $\bar{a}^{\mathrm{P}} i d$ is addressed to Muslims and Jews, with the intention of giving them the true teaching of Christian dogmas (without any specification of Christian denomination). It can be asserted, further, that the Book is written also for Christians; its beauty and elegance of style allow them to enjoy arguments based on Christian dogmas and to be proud of the great heritage of their belief. They can say together with ${ }^{\mathrm{c}} \mathrm{A} \underline{\mathrm{b}} \mathrm{d} \overline{\mathrm{s}} \mathrm{su}^{\mathrm{c}}$ :

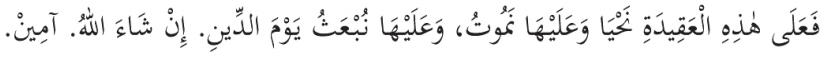

"Upon this doctrine we live, and for it we die, and upon it we rise from the dead on the Day of Judgment, if God is willing. Amen.” (233-234 KFF) 


\subsection{The Concept of the Kitāb fară $\bar{a}^{\top}$ al-faw $\bar{a}^{\supset} i d$}

The Kitāb farāoid al-fawā’id is a Christian dogmatic and apologetic book. It is written in thirteen chapters. It was composed in Arabic, in a very high literary style, imitating the Qur'anic style and employing Qur'anic expressions. Many parts of the text are written in rhyme (musa $\left.\breve{g} \breve{g} a^{c}\right)$. It is addressed first of all to Muslims, but also to Jews, with the intention of giving them detailed explanations of the central Christian dogmas and of proving that Christians are not polytheists. For this dual purpose, both in the introduction to the book and in the first chapter, ${ }^{\mathrm{C}} \mathrm{A} \underline{\mathrm{b}} \mathrm{d} \overline{\mathrm{i}} \overline{\mathrm{s}}^{\mathrm{c}}{ }^{\mathrm{c}}$ calls the reader to dialogue in sincere mutuality, with respect for reasons and arguments.

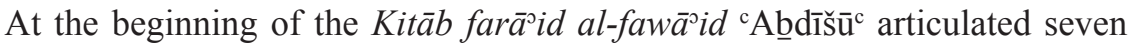
Principles of the Religion. They are the following:

1) The world is originated ( $31 K F F)$;

2) The world has the Originator $(32 K F F)$;

3) God is One, and His Attributes of the Essence are three $(33 \mathrm{KFF})$;

4) The statement on the Incarnation (Indwelling) and on the Unity in Christ $(34 K F F)$;

5) The advent of Christ is true, and the Gospel is truthful and Christianity is right $(35 \mathrm{KFF})$;

6) The necessity of the abrogation of the ancient laws and the impossibility of the abrogation of the law of our Lord Christ (36 KFF);

7) The statement on the Resurrection of the dead and the Last Day ( $37 K F F)$.

Kawerau, "Ebed Jesus: Der Abschluß des antiochenischen Theologie".

3

Paša, Kitāb farāoid al-fawāo id fì ușūl ad-dīn wal- ${ }^{c} a q \bar{a}^{\urcorner} i d .$.

\section{4}

Assemanus, Bibliotheca Orientalis Clementino-Vaticana, II, pp. 509-510; III/I, pp. 586589; Mai, Scriptorum veterum nova collectio, IV, pp. 224-227.

5

Troupeau, Catalogue de manuscrits arabes. Première partie: Manuscrits chrétiens, I, pp. 176-178.

6

Sachau, Verzeichnis der syrischen Handschriften der Königlichen Bibliothek zu Berlin, pp. 407-415; Ahlwardt, Verzeichniss der arabischen Handschriften, 546b-547a, no. 10183.

7

Cheikho, Catalogue des manuscrits des auteurs arabes chrétiens, pp. 341-342.

8

Sacerdote, I codici ebraici della Pia Casa de Neofiti in Roma, no. 41, p. 6.

Wright, A Catalogue of Syriac Manuscripts Preserved in the Library of the University of Cambridge, 2, pp. 754-792.
10

$K F F$ is an abbreviation for the Kitāb farāa $i d$ al-fawāo id fì ușūl ad-dīn wal-caq āoid. Numbers which precede this abbreviation inside parentheses indicate verses from the critical edition. See footnote 3 above and the related reference in the "Bibliography" below.

11

Reference from the Quraan, 2:62. The complete verse is:

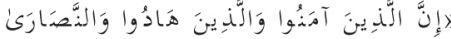

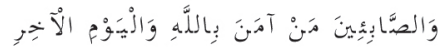

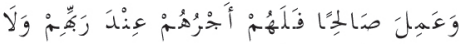

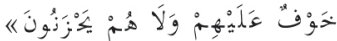

"Indeed the faithful, the Jews, the Christians, and the Sabaeans - those of them who have faith in Allah and the Last Day and act righteously - they shall have their reward near their Lord, and they will have no fear, nor will they grieve."

12

Samir, "Une profession de foi de ${ }^{\mathrm{c}} \mathrm{Abdišu} \mathrm{u}^{\mathrm{c}}$ de Nisibe".

13

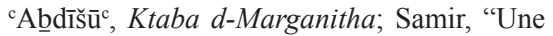
profession de foi de "Abdišuc de Nisibe", vv. 24-36, p. 439. 
Seven Principles of the Religion are explained in the following thirteen chapters of the Book.

${ }^{\mathrm{c}} \mathrm{A} \underline{\mathrm{b} d} \mathrm{~d} \overline{\mathrm{s}} \mathrm{u}^{\mathrm{c}}$ 's list of the Principles has its proper originality. He based his selection of the Principles on the things which are common for all religions and on the issues acceptable for all. He started and finished his book with the Principles acceptable for all religions.

From the first up to the third Principle (God is One), the Principles are common among Muslims, Jews, and Christians. But the second part of the third Principle, "and His Attributes of the Essence are three", is the point at which "A $\underline{b} d \overline{1} \bar{s}{ }^{c}{ }^{c}$ introduced the specific Christian belief in the One-Triune God based on the theology of attributes.

In the following two chapters the paper presents ' $\mathrm{A} \underline{b} \mathrm{~d} \overline{\mathrm{s}} \mathrm{s}^{\mathrm{u}}{ }^{\mathrm{c}}$ 's teaching on God's Oneness and Threeness, and the Attributes (sifät) of God through the analysis of the first three Principles of Religion.

\section{The Oneness of God}

One of the most important and fundamental statements in the Kitāb farāo $i d$ alfaw $\bar{a}^{\top} i d$ is the frequent emphasis that Christians are monotheists and that they believe in only one, unique God. 'A ${ }^{\mathrm{b}} \mathrm{d} \overline{\mathrm{i}} \overline{\mathrm{s}} \mathrm{u}$ 's $\mathrm{s}$ intent was to eliminate unjust and unfounded accusations of polytheism. He categorically claimed:

"We, the community of the Christians, the monotheists, believe and have faith that God (the Exalted One!) is a unique one (واحد أحد )." (171 KFF)

To demonstrate the Oneness of God, ${ }^{c} A \underline{b} d \overline{1} \breve{s} \bar{u}^{c}$ engages logical reasoning and the theology of attributes from the philosophy of Kalām. ${ }^{14}$

\subsection{The evidence for the existence of God}

In the demonstration of the Oneness of God, ${ }^{c} \mathrm{~A} \underline{b} \mathrm{~d} \overline{1} \bar{s} \bar{u}^{\mathrm{c}}$ first starts with visible reality in order to come to a proof of the existence of God. Secondly, from the evidence of the existence of the world he arrives at the fact that the world is not of itself but from another. So, if the world does not have existence in itself, then there is someone else from whom the world is originated. Finally, this conclusion leads to the next - that the world has its Originator and that he should to be only one. Hence, from visible reality ${ }^{\mathrm{C}} \mathrm{A} \underline{b} \mathrm{~d} \overline{\mathrm{i}} \overline{\mathrm{s}}^{\mathrm{c}} \mathrm{c}$ arrives at invisible reality. ${ }^{15}$ From the evidence of the visible worlds ${ }^{\mathrm{c}} \mathrm{A} \underline{b} \mathrm{~d} \overline{\mathrm{i}} \overline{\mathrm{u}}^{\mathrm{u}}{ }^{\mathrm{c}}$ concludes the Oneness of God.

\subsubsection{The world is originated (236-248 KFF)}

The statement that the world is originated is ' $\mathrm{A} \underline{\mathrm{b}} \mathrm{d} \overline{\mathrm{i}} \mathrm{s} \mathrm{u}^{\mathrm{c}}$ 's first Principle of Religion. So, he starts with the observation of the visible evidence.

Firstly, he examines the nature of being in general. The being can be infinitely pre-existent or temporally originated. If it is infinitely pre-existent, it has neither a beginning nor an end. It is not limited (237-238 KFF). On the other hand, a temporally originated being has a beginning and an end. It is limited $(240 \mathrm{KFF})$ and is opposite to the infinitely pre-existent even in its attributes $(239 K F F)$.

Secondly, the world, as the concretely being (but without specification), is either finite or infinite. If it is finite, it is originated $(241 \mathrm{KFF})$. Proof for its finality is its composition and motion. As for composition, the world is 
composed of heaven and other things which are contained by the heaven (242 $K F F) .{ }^{16}$ As for motion, the heaven is determined by the movements of the planets, constellations, spheres, and four principal elements: earth, water, air, and fire $(243 K F F)$. Each being determined by movement is finite. Hence the heaven, along with all things which it contains, is finite $(244-245 \mathrm{KFF})$. Since the world includes the things contained in it and their finitude, so the world is finite (246-247 KFF). Each finite being is originated. Consequently, the world is originated ( $248 \mathrm{KFF}$ ), and this is the first Principle of Religion upon which ${ }^{\mathrm{c}} \mathrm{A} \underline{\mathrm{b}} \mathrm{d} \overline{\mathrm{i}} \overline{\mathrm{u}}^{\mathrm{u}} \mathrm{c}$ builds other Principles.

In conclusion, it can be said that the first Principle reflects Aristotle's Book XII (Lambda) from his Metaphysics, which presents the beings in general, first principles, and God as "the most divine of things observed by us", as "the thinking of thinking". "A $\underline{b} d \overline{1} \overline{s ̌}_{\bar{u}}^{\mathrm{c}}$ 's mode of exposition of his first Principle is the method of deductive reasoning based on Aristotle's logic.

\subsubsection{The world has its Originator (249-263 KFF)}

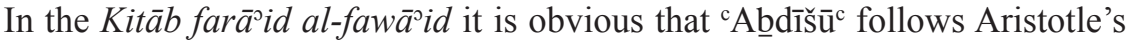
teaching in many of its segments, but he is not in agreement with all of them. Thus, for Aristotle the world is not created nor did it come into being at one point, but it has existed, unchanged, for all eternity, and it had to be that way since it was perfect. For ${ }^{\mathrm{c}} \mathrm{A} \underline{\mathrm{b}} \mathrm{d} \overline{\mathrm{i}} \overline{\mathrm{u}}^{\mathrm{c}}{ }^{\mathrm{c}}$ the world was created, has its Creator and is not perfect.

However, "A $\underline{b}$ dīšùu builds the second Principle, "the world has the Originator", upon the first Principle. Since, from the first principle, it was evident that the world is originated, he continues with this reasoning. That the world is originated means that it was without existence and then came into existence $(250 \mathrm{KFF})$. So, it should have a maker who brings it from non-existence into existence. This maker can be either itself, or something outside of and different from itself $(251-252 \mathrm{KFF})$. It is not possible that the world brings itself into existence, because only one who has existence can lead another into existence (253-254 KFF). Hence, it can only be, then, that the world received existence from someone existent and different from itself $(255-256 \mathrm{KFF})$.

14

"The Philosophy of Kalam" ('Ilm al-Kalām, is the Islamic philosophical discipline of seeking theological principles through dialectic. Kalām (= speech, words). In Islamic practice, this relates to the discipline of seeking theological knowledge through debate and argument. A scholar of kalām is referred to as a mutakallim (pl. mutakallimūn). There are many possible interpretations as to why this discipline was originally called kalàm; one is that the widest controversy in this discipline has been about whether the Word of God, as revealed in the Qurān, can be considered part of God's essence and therefore not created, or whether it was made into words, in the normal sense of speech, and is therefore created. Cf. Gardet, "IIlm al-Kalām"; Wolfson, The Philosophy of the Kalam.

15

A similar methodology of reasoning is found in the Quinque viae by Thomas Aquinas (Summa Theologiae, I, q. 2, a. 3) and in his epistemology, where Aquinas points out that human intellect "through natures of visible things rises to certain knowledge of invisible things" (Summa Theologiae, I, q. 84, a. 7 co.).

16

Aristotle developed a physical cosmology of spheres. In it, the spherical Earth is at the centre of the universe and the planets are moved by either 47 or 55 interconnected spheres that form a unified planetary system. Aristotle, Metaphysics, 1073b1-1074a13. Aristotle held that these spheres are made of an unchanging fifth element, the aether. Each of these concentric spheres is moved by its own god, an unchanging divine unmoved mover who moves its sphere simply by virtue of being loved by it. "The final cause, then, produces motion by being loved, but all other things move by being moved" (Aristotle, Metaphysics, 1072b4). 
Moreover, the Principle has already been established that two similar matters should both be judged with the same judgment. ${ }^{\mathrm{c}} \mathrm{A} \underline{\mathrm{b}} \mathrm{d} \overline{\mathrm{s}} \mathrm{u}^{\mathrm{c}} \mathrm{c}$ applies this principle to judgment regarding the world (257-258 KFF). There are two worlds or two cosmoses: the macro and the micro. The macro-cosmos is the world in its totality (260 KFF), while the micro-cosmos is the human being (261 KFF). As for the human being or the micro-cosmos, it is evident that it has a maker and creator $(262 \mathrm{KFF})$, so the world or the macro-cosmos must also have a maker and a creator. Therefore, ${ }^{c} A \underline{b} d \overline{1} \check{s}^{\mathrm{s}} \bar{u}^{\mathrm{c}}$ can conclude that the world has an Originator.

\subsubsection{The Originator is One (264-293 KFF)}

The third Principle proceeds from the first two Principles. In the first treatise, it was proved that the world is originated, in the second that it has an Originator. The third treatise proves that the Originator is only one.

However, ${ }^{\mathrm{C}} \mathrm{A} \underline{\mathrm{b}} \mathrm{d} \overline{\mathrm{s}} \mathrm{u}_{\mathrm{u}}{ }^{c}$ 's reasoning is based on two hypothetical examples. The first example (267-276 KFF) is based on the hypothesis that, if the world has more than one Maker, then there will be a problem regarding their power. If each of them has the same power, one cannot vanquish the other, and it will not be possible to create the world (268-271 KFF). If their powers are not equal, the stronger one will vanquish the weaker, and the stronger will be the maker of all. The weaker has no possibility of creating the world (272-274 KFF).

The second example $(277-281 K F F)$ is based on the experience of human nature. When many actors are engaged in the same matter, they spoil the matter, because their actions are based on different opinions, powers and expectations $(279 \mathrm{KFF})$. If it is like that, even with the unimportant matters in ordinary human life, it will be even more problematic in the larger world, unless that larger world has only one maker $(281 \mathrm{KFF})$.

Hence, there is only One Maker of the world, with no partner beside him (282 $K F F$ ), and he is nothing other than Being itself. He exists by himself and not by another, because existing by another means to have need of another for existence (283-286 KFF). ${ }^{17}$ So, the Creator of the world is Substance, because he exists in himself $(289 \mathrm{KFF})$. He is only one substance, but He has three Attributes in His Essence, neither more nor fewer (290-293 KFF).

Therefore, the conclusion that the Creator is only one, with three Attributes, provides the introduction to the treatise which is the exposition on the Trinity. But, before observation of the treatise on the Threeness of God, it is necessary to observe ${ }^{c} A \underline{b} d \overline{1} \bar{s}_{\bar{u}}$ 's 's engagement of the theology of divine attributes as evidence of the Oneness of God.

\subsection{The divine attributes}

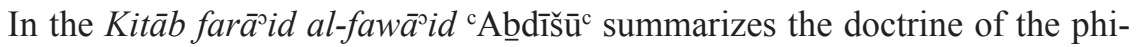
losophy of the Kalām and applies it to the Christian doctrine, finding accord to support the dogmatic teaching regarding the unity of God. In spite of this, he employs the high Qur'anic style, using many expressions for the attributes of God which are known as "the beautiful names of God" ('asmāa allāh alhusnāa $)^{18}$ in Islam. So, in that way, ${ }^{\mathrm{c}} \mathrm{A} \underline{\mathrm{b}} \mathrm{d} \overline{\mathrm{s}} \mathrm{u}^{\mathrm{c}}$ intended to confirm that Christians are not polytheistic.

However, the divine attributes which ${ }^{\mathrm{c}} \mathrm{A} \underline{b} \mathrm{~d} \overline{\mathrm{i}} \overline{\mathrm{s}}^{\mathrm{u}}{ }^{\mathrm{e}}$ employs as support for his demonstration of Christian belief in God's unity can be classified into five groups: (1) attributes of the Transcendence of God; (2) attributes of the Maj- 
esty and Power of God; (3) emphasized attributes; (4) apophatic descriptions of God; (5) attributes of action.

\subsubsection{Attributes of the Transcendence of God}

Attributes of the Transcendence of God are as follows: Exalted One! $\left(t^{\mathrm{c}} \bar{a} l \bar{a}\right)^{19}$ (172 KFF), Holy (al-qudus) (174 KFF), above constraints ('an al-iğb $\bar{a} r$ ) (174 KFF), above compulsions ('an al-idtirār) (174 KFF), above time ('an al-zamān) (177 KFF), above place ('an al-makān) (177 KFF), above the passions for changing and newness (177 KFF), above all things ${ }^{20}(178 \mathrm{KFF})$, transcendent above all things $\left(m u t^{\mathrm{c}} \bar{a} l^{\mathrm{c}} \text { ala } \mathrm{kull} \text { ša } y^{\mathrm{o}}\right)^{21}(178 \mathrm{KFF})$, and Knower

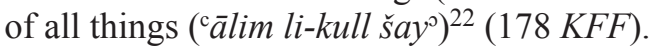

\subsubsection{Attributes of the Majesty and Power of God}

Attributes of the Majesty of God are as follows: Maker of what He wills by choice (hakīm fā'il li-mā yašă lah bil-ihtiyār) (174 KFF), All-Mighty (al$\left.{ }^{\mathrm{c}} a z \overline{i z}\right)^{23}(175 \mathrm{KFF})$, the Conqueror (al-qahhār) ${ }^{24}(175 \mathrm{KFF})$, the Able (qādir) $(178 \mathrm{KFF})$; to Him belongs the exalted attributes (lah al-sifät al- $\left.{ }^{\mathrm{c}} \bar{a} l y \bar{a} t\right)(179$ $K F F$ ), the Most Beautiful Names of highest perfection (lah al-asmāo al-husnā min al-kamāl al-asmā) (179 KFF), and the most brilliant beauty (al-ğamāl al-asnā) (179 KFF); Owner of matter and creation (mālik al-amr w-al-halq) $(181 \mathrm{KFF})$ and Rich in the absolute (al-ganī al-muțlaq) (182 KFF).

\subsubsection{Emphasized Attributes (tawkīd)}

Emphasized attributes occur always in pairs, two attributes together. This is a special Arabic style known as tawkīd. It is the strengthening or corroboration of the words by emphatic repetition of the word itself, or by the addition of

17

${ }^{c} \mathrm{~A} \underline{b} d \overline{1} \bar{s} \bar{u}^{\mathrm{c}}$ 's exposition on one maker as "Being itself" has similarity with Thomistic philosophy on "ipsum esse". Cf. Thomas Aquinas, Summa Theologiae, I, q. 3, a. 4; I, q. 3, a. 7; I, q. 4, a. 2; I, q. 4, a. 3; I, q. 6, a. 3, arg. 2; I, q. 7 , a. 1.; etc.

18

"The most beautiful names of God" ('asmā allāh al-husnā, أسماء الله الحسنى), also known as "the 99 names of God", are the names of God mentioned in the Qur'an and by which $\mathrm{Mu}$ slims regard God. According to hadith there is a special group of 99 names, but there is no enumeration of them. According to a hadith narrated by ${ }^{\mathrm{c}} \mathrm{Abdullāh}$ ibn Mas ${ }^{\mathrm{c}} \overline{\mathrm{u}} \mathrm{d}$, the last name, the hundredth name of God, will be hidden from mankind until the Last Day, when God will reveal it. Some Christians, knowing this hadith, say that this hidden name is "the Father" and that this name will be revealed to Muslims on the Last Day. Therefore, there are not only 99 names of God, but more. Cf. Gardet, "Al-`asmā̄ al-Ḥusnā”.

19

Qur'an 6:100; 7:190; 10:18; 16:1; 16:3; $17: 43 ; 20: 114 ; 23: 92.116 ; 27: 63 ; 28: 68$; $30: 40 ; 39: 67 ; 72: 3$.
20

Qur'an 6:37.65; 17:99; 36:81; 46:33; 75:40; 86:8.

21

Qur'an 13:9

22

Qur'an 6:73; 9:94.105; 13:9; 23:92; 32:6; $34: 3 ; 35: 38 ; 39: 46 ; 59: 22 ; 62: 8 ; 64: 18$; $72: 26$

23

Qur'an 2:129.209.220.228.240.260; 3:4.6.18 $62.126 ; 5: 38.95 .118 ; 6: 96 ; 8: 10 ; 8: 49.63 .67$; $9: 40.71 .128 ; 11: 66.91 ; 12: 30.51 .78 .88 ; 14: 1$. $4.20 .47 ; 16: 60 ; 22: 40.74 ; 26: 9.68 .104 .122 .1$ $40.159 .175 .191 .217 ; 27: 9.78 .26 .42 ; 30: 5.27$; $31: 9.27 ; 32: 6 ; 34: 6.27 ; 35: 2.17 .28 ; 36: 5.38$; $38: 9.66 ; 39: 1.5 .37 ; 40: 2.8 .42 ; 41: 12.41 ; 42$ : $3.19 ; 43: 9 ; 44: 42.49 ; 45: 2.37 ; 46: 2 ; 54: 42$; $57: 1.25 ; 58: 21 ; 59: 1.23 .24 ; 60: 5 ; 61: 1 ; 62: 1.3$; $64: 18 ; 67: 2 ; 85: 8$.

24

Qur'an 12:39; 13:16; 14:48; 38:65; 39:4; 40:16. 
a pronoun (suffix or corresponding separate pronoun) or by substitution (albadal). ${ }^{25}$ In emphasized attributes, there is a repetition of God's name itself, which provides emphasis and gives strength to the expression.

The emphasized attributes are as follows: Unique One (wāhid ahad) (172 $K F F$ ), Eternally Living (qadìm hayy) (173 KFF), the Most Merciful and Most Gracious (al-rahman al-rahim) $(180 \mathrm{KFF})$, the Great Lord (al-rabb al-'azìm ${ }^{26}(180 \mathrm{KFF})$, the Magnanimous Benefactor (al-ğawwād al-karīm) $(180 \mathrm{KFF})$, the Truer Justice (al- ${ }^{\mathrm{c}}$ adl al-așdaq) (182 KFF), the Provident Ruler (al-mudabbir al-muwaffiq) (182 KFF), Truthful Light (al-nūr al-sidq) (181 $K F F)$, Unquestioned Judge (al-dayyān al-muhaqqaq) (181 KFF), and Truth King (al-malik al-haqq) (181 KFF).

\subsubsection{Apophatic description of God}

The apophatic description of God can be divided in two classes. The first class describes God's transcendence (Deus in se), while the second class describes God's relation with creatures (Deus a se).

In the first class (Deus in se) are found the following descriptions: There is no god except Him Alone (lä ilah illā huwa wahdahu) ${ }^{27}(175 \mathrm{KFF}$ ), He has no partners (lā šarīka lahu $)^{28}(175 K F F)$, He is not comprehended by perception (lā tudrikuhu al-abșār) (175 KFF), He is not encompassed by thoughts (lā tuhìt bihi al-afkār) ${ }^{29}(175 \mathrm{KFF}$ ), and He has not limitation (lā hadd lahu) $(176 \mathrm{KFF})$.

In the second class (Deus a se) are found the following descriptions: God is not possible to portray (la rasm lahu) (176 KFF), none is similar to Him (la šibhan lahu) (176 KFF), and He has not a body (lä ğisman lahu) (176 KFF).

\subsubsection{Attributes of action}

While the Attributes of Essence, as substances, exist by themselves, the attributes of action are always indicative of relationship with another essence. They can be understood only by adding another essence in relation to the Divine Essence (304 KFF). The attribute 'the Creator' reveals the necessity of 'a creature' (304 KFF), 'the Able' needs one over whom to exercise Divine ability, and 'the Forgiver' needs one who is forgiven (305 KFF). This holds true for all the attributes of action.

The most important attribute of action is 'the Originator' with His relation to the 'originated'. These attributes are significant in the first three Principles of Religion (31-33 KFF): the world is originated $(31,236-248 \mathrm{KFF})$ and it has the Originator $(32,249-263 K F F)$ and the Originator is One $(33,265-293$ $K F F$ ).

'The Originator' is a translation of the Arabic word muhdit (sُخِدِث ), and 'originated' is a translation of the Arabic word muhdat ( مُحدَثَ ). Both words are derived from the verb 'ahdața (احدث) ( احت ). This verb is from the IVth class

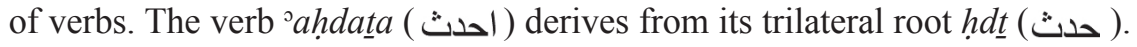
The primary meaning of $h d \underline{t}$ (حدث) is related to creation: to bring into being or existence, to cause something to be, to produce, to create, to originate, to generate, to give rise to, to make something newly, to cause, to effect. ${ }^{30}$ The secondary meaning of $h d \underline{t}($ (حدث) is related to conversation or relations: to tell (about), to report to (about), to relate to (about), and to converse with (about something). ${ }^{31}$ The word 'Hadith' (hadīt) is derived from the same trilateral root and has the meanings: speech, chat, talk, conversation, discussion, 
interview, tale, narrative, and relating the deeds and utterances of the Prophet and his Companions. ${ }^{32}$

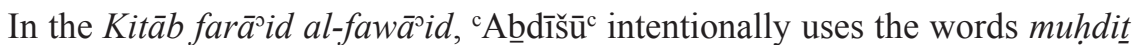

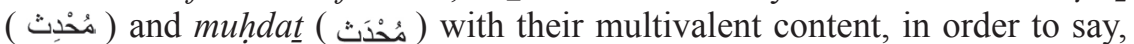
firstly, that God is the Originator (Creator) and, secondly, that the world is

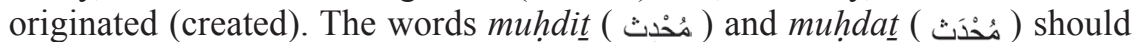
also be understood in their original meanings, from the trilateral root $h d t$ ( حدث ( This means that they should be understood both in the meaning of creation or origination and in the meaning of the expression or conversation.

The word muhdiț ( مُحْدث ) is an active participle, denoting the agent (nomen agentis, اسم الفاعل). In the context of the text, the agent is God. Therefore, the word muhdit ( هُحْدث ) can be translated with both its meaning as One who is bringing [something] into being or existence, who is causing [something] to be, and its meaning as one who is originating or creating [something] (primary meaning) through talking, speaking, conversation or relations (secondary meaning). The Originator is One and is the one who is saying-creating or conversing-originating. So, the translated word 'Originator' comprehends all these meanings.

The word muhdat ( هُحَدَث ) is a passive participle, denoting the patient (nomen patientis, اسم المفعول). In the context of the text, the patient is the world, the world understood as a collective noun. Therefore, the word muhdat ( 1 (sْدَثَ ) can be translated with both its meanings, both as that which is brought into being or existence, which is caused to be, and as that which is originated or created (primary meaning) through talking, speaking, conversation or relations (secondary meaning). It is what is by-saying-created or by-conversingoriginated. So, the translated word 'originated' comprehends all these meanings.

It should not be considered strange that ${ }^{\mathrm{c}} \mathrm{A} \underline{\mathrm{b}} \mathrm{di} \overline{\mathrm{s}} \mathrm{u}^{\mathrm{c}}$, as a great theologian, has hidden his theological Trinitarian view on the mystery of creation by using the words muhldit ( مُحْدِث ), 'Originator', and muḥdat ( مُحَْثَث), 'originated'.

25

Wright, A Grammar of the Arabic Language, pp. 282-283.

26

Qur'an 56:74.96; 69:54

27

Qur'an 2:168.255; 3:2.6.18; 4:87; 6:102.106. $158 ; 9: 31.129 ; 10: 90 ; 11: 14 ; 13: 30 ; 16: 2$; $20: 8.14 .98 ; 21: 25.87 ; 23: 116 ; 27: 26 ; 28: 70$. $88 ; 35: 3 ; 37: 35 ; 39: 6 ; 40: 3.62 .65 ; 44: 8$; $47: 19 ; 59: 22.23 ; 64: 13 ; 73: 9$

28

Qur'an 6:163; 17:111; 25:2.

29

Reference to Qur'an 6:103,

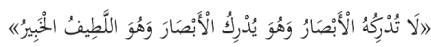

"The sights do not apprehend Him, yet $\mathrm{He}$ apprehends the sights, and $\mathrm{He}$ is the All-attentive, the All-aware", and Qur'an 27:84,

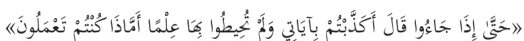

"When they come, He will say, 'Did you deny My signs without comprehending them in knowledge? What was it that you used to do?'”.

30

Cf. احدث in Lane, An Arabic-English Lexicon, 1, p. 528, § 4; Wehr, A Dictionary of Modern Written Arabic, p. 161.

31

Cf. حدث in Lane, An Arabic-English Lexicon, 1, p. 527, § 1; Wehr, A Dictionary of Modern Written Arabic, p. 161.

32

Cf. حدث in Lane, An Arabic-English Lexicon, 1, p. 529; Wehr, A Dictionary of Modern Written Arabic, p. 161.

33

Grammatical meaning of active and passive participles in Arabic language, with a lot of examples; see Wright, A Grammar of the Arabic Language, p. 52, § 80; p. 109, § 192; pp. 129-130, § 227; pp. 131-133, § 229-230. 


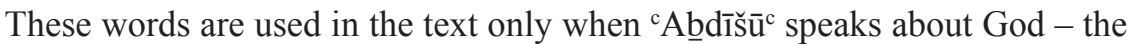
Trinity - in His relation to the world (Deus ad extram). ${ }^{34}$

Such a theological interpretation of the words muhdit ( مُحْدِث ( ) muhdat

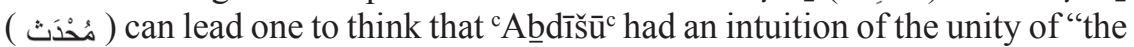
Economic Trinity" and "the Immanent Trinity". 35 "The Immanent-Economic Trinity" is the originating of the world through inner intercommunication. It is saying-creating or conversing-originating all the universe. On the other hand, the world is originated through the intercommunication of "the Immanent-Economic Trinity". However, 'A $\underline{b} d \overline{1} \bar{s} \bar{u}^{c}$ 's Trinitarian teaching will be observed in following section.

\section{The Threeness of God}

The previous section observed the first Principle - that the world is originated; the second Principle observed that the world has the Originator, and the first article of the third Principle that the Originator is One. Up to this point, the teaching on God is acceptable both for Muslims and for Jews. In the second article of the third Principle, that God's Attributes of Essence are Three, ${ }^{\mathrm{c}} \mathrm{A} \underline{\mathrm{b}} \mathrm{d} \overline{\mathrm{s}} \mathrm{u}^{\mathrm{c}} \mathrm{introduces}$ the exposition of the Christian treatise on the Trinity, which Muslims and Jews reject. In order to make the Christian mystery of the Triune God more understandable and acceptable, ${ }^{\mathrm{c}} \mathrm{A} \underline{\mathrm{b}} \mathrm{d} \overline{\mathrm{s}} \mathrm{u}^{\mathrm{c}}{ }^{\mathrm{c}}$ uses the theology of attributes, with strong Qur'anic expressions and the Islamic terminology of the Philosophy of the Kalām.

\subsection{The Essence of God}

'A $\underline{b} d \overline{1} \bar{s}^{c}{ }^{c}$ 's exposition on the Threeness of God highlights several points, starting with the observation of the pure essence of God. This essence is first observed deprived of any additions, and then is considered in its relation with God's attributes (295-300 KFF). These attributes are divided into two main groups (301-306 KFF). First are the three essential Attributes of the Essence $(302-303 \mathrm{KFF})$ and then the attributes of action or attributes in relation with creatures (304-306 KFF).

However, ${ }^{c} \mathrm{~A} \underline{b} d \overline{1} \breve{s} \bar{u}^{\mathrm{c}}$ recognizes that, in order to speak of what is God in Himself, it is necessary to try to understand His Essence. This Essence of God should be observed deprived of any attributes. The Essence of God is one from all aspects, with no multiplication under any circumstance (224 KFF). This Essence is Substance ( $\breve{g}$ awhar) because it subsists by itself, and it does not exist by another $(225 \mathrm{KFF})$.

Moreover, because of His Essence, God is only one and unique (wähid ahad) $(307 \mathrm{KFF})$. He exists in Himself and does not exist by another (308 KFF). There is no existence except in Him and by Him. But He has existence by Himself. That One who has existence by Himself is called Substance ( $\breve{g} a w h a r)$.

Furthermore, the observation of the pure essence of God is followed by a deeper observation of the Creator in Himself, in his essence, "Deus ad intram" (307-316 KFF). The observation results in the proof that the Creator in Himself is the only One Essence (307-311 KFF). Considered in light of the three properties of this Essence, God is the Eternal in Essence (312 KFF), the Wise in Essence (313-315 KFF), and the Living by Essence (316 KFF). So, the One and Unique Essence of God manifests itself by its own properties as the Father and the Son and the Holy Spirit (317-329 KFF). 
In the conclusion, ${ }^{\mathrm{c}} \mathrm{A} \underline{b} \mathrm{~d} \overline{\mathrm{i}} \mathrm{s} \bar{u}^{\mathrm{c}}$ calls for weighing the explicated doctrine of the Trinity "with the balance of intellect [...] [in order] to consider it with fairness and respect" (343-345 KFF).

In addition, the treatise is overflowing with the Qur'anic attributes of God, the

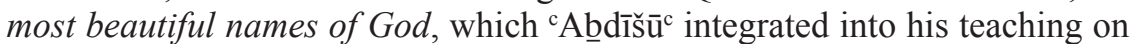
the Trinity. In that way, the Qur'an is used as implicit proof and confirmation for the doctrine of the Holy Trinity. ${ }^{36}$

\subsection{The Attributes of the Essence of God}

Observing the Substance of God, it appears that it requires three essential and subsisting Attributes. They are the Necessity of Existence (wuğ $\bar{u} b$ al-wuğ $\bar{u} d$ ) $(172,226 \mathrm{KFF})$, the Wisdom (al-hikma) $(226 \mathrm{KFF})$ and the Life (al-hayāt) $(226 K F F)$.

However, ${ }^{\mathrm{C}} \mathrm{A} \underline{\mathrm{b} d} \mathrm{~d} \bar{s} \bar{u}^{\mathrm{c}}$ explains that the Necessity of Existence (wuğūb al-wuğūd) $(226 \mathrm{KFF})$ is also called the Eternal in Essence (al-qadìm bi-d $\underline{d} \bar{d} \bar{a} t)(229 \mathrm{KFF})$,

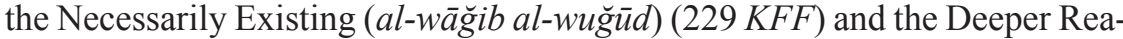
son for all that exists ( ${ }^{\mathrm{c}}$ illat $\breve{g} a m \imath^{\mathfrak{c}}$ al-mawğ $\left.\bar{u} d \bar{a} t\right)(229 \mathrm{KFF})$. The Wisdom (al-hikma) is also called the Wise (al-hakim) (174, $230 \mathrm{KFF})$. The Life (alhayat) $(226 \mathrm{KFF}$ ) is also called the Living-Subsisting (al-hayy al-qayyüm) $(230 K F F)$.

So, the essential attributes of God are these three:

1) the Necessity of Existence (wuğ $\bar{u} b$ al-wuğ $\bar{u} d)(226 \mathrm{KFF})$ or the Eternal in Essence (al-qadìm bi- $\underline{d} \underline{d} \bar{a} t)(310 \mathrm{KFF})$;

2) the Wisdom (al-hikma) (226 KFF) or the Wise in Essence (al-hakim bidd $\underline{d} \bar{a} t)(311,313 \mathrm{KFF})$;

3) the Life (al-hayāt) (226 KFF) or the Living in Essence (al-hayy bi-d्d $\underline{d} \bar{a} t)$ $(316 K F F)$.

Moreover, these three attributes of God ${ }^{\mathrm{c}} \mathrm{A} \underline{\mathrm{b}} \mathrm{d} \overline{\mathrm{i}} \overline{\mathrm{u}}^{\mathrm{u}} \mathrm{c}$ calls qnome $(227 \mathrm{KFF})$. The qnoma "is the taking of the essence along with the property from its appropriate attribute" $(228 \mathrm{KFF})$. So these qnome are, and can only be, three, and the three are these:

1) the Father, who is the Eternal in Essence (al-qadīm bi-d $\underline{d} \underline{d} \bar{a} t)$, Necessarily Existing ( $a l-w \bar{a} \breve{g} i b$ al-wuğ $\bar{u} d$ ), the Deeper Reason for all that exists ('illat $\breve{g} a m \imath^{\complement}$ al-mawğ ūdāt) $(229 \mathrm{KFF})$;

2) the Son, who is the Wise (al-hakim) (230 KFF);

3) the Holy Spirit, who is the Living-Subsisting (al-hayy al-qayyūm) (230,

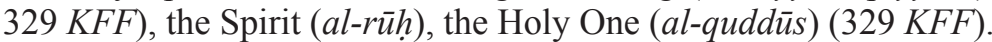

34

The usage of the word muhdit (مُحْدث) in the Kitāb far $\bar{a}^{\circ} i d$ al-faw $\bar{a}^{\circ} i d$; see in numbers 32 , $45,235,254,265,287,291 \mathrm{KFF}$; the usage of the word muhdat (sْدَثن) see in numbers 31, 44, 183, 235, 237, 239, 240, 241, 247, 248, 250, 265, 291, $375 \mathrm{KFF}$.

35

See chapter "The Axiomatic Unity of the 'Economic' and 'Immanent' Trinity" in Rahner, The Trinity, pp. 21-24.
36

The treatise should, on the one hand, be understood in the light of the classical Christian Arabic apologetic theology of attributes and analogies, and, on the other, within the context of the Muslim philosophy of the Kalām and its theology of the divine attributes. Cf. Haddad, La Trinité divine chez les théologiens arabes (750-1050), pp. 187-245; Wolfson, "The Muslim Attributes and the Christian Trinity"; Sadowski, The Trinitarian Analogies in the Christian Arab Apologetical Texts...; Caspar, Théologie Musulmane, pp. 52-60. 
Between the Father and the Son there is a relation. The Father is the Cause for the existence of the Son, and the Father is prior to the Son by his character $\left(a l-t a b^{c}\right)(319 K F F)$. The three Attributes of God (226 KFF) can be schematically displayed as follows:

\begin{tabular}{|c|c|c|c|}
\hline \multirow{4}{*}{ 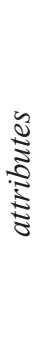 } & \multicolumn{3}{|c|}{$\begin{array}{l}\text { the One (wāhid) } \\
\text { the Unique }(a h a d)\end{array}$} \\
\hline & $\begin{array}{l}\text { the Necessity of Existence } \\
\qquad(w u \breve{g} \bar{u} b a l-w u \breve{g} \bar{u} d)\end{array}$ & $\begin{array}{c}\text { the Wisdom } \\
(\text { al-hikma })\end{array}$ & $\begin{array}{l}\text { the Life } \\
(\text { al-hayāt) }\end{array}$ \\
\hline & $\begin{array}{l}\text { the Necessarily Existing } \\
(a l \text {-wāğib al-wuğ } \bar{u} d)\end{array}$ & $\begin{array}{l}\text { the Wise } \\
\text { (al-hakīm) }\end{array}$ & $\begin{array}{c}\text { the Living-Subsisting } \\
\text { (al-hayy al-qayyūm) }\end{array}$ \\
\hline & $\begin{array}{l}\text { The Eternal in His Essence } \\
\text { (al-qadim bi-d } \underline{d} \underline{d} \bar{a} t)\end{array}$ & $\begin{array}{l}\text { The Wise in Essence } \\
(\text { al-hakim bi-d } \underline{d} \underline{d} \bar{a} t)\end{array}$ & $\begin{array}{l}\text { The Living in Essence } \\
\text { (al-hayy bi- } \underline{d} \underline{d} \bar{a} t)\end{array}$ \\
\hline $\begin{array}{l}\text { ई } \\
\text { ई } \\
\text { s }\end{array}$ & $\begin{array}{l}\text { the Father } \\
\qquad(a l-\bar{a} b)\end{array}$ & $\begin{array}{l}\text { the Son } \\
(a l-i b n)\end{array}$ & $\begin{array}{l}\text { the Holy Spirit } \\
\text { (ruh al-qudus) }\end{array}$ \\
\hline
\end{tabular}

In addition, in exposing the teaching of the attributes of the Trinity (330$342 K F F),{ }^{c} \mathrm{Ab} \underline{b} \bar{i}^{2} \bar{u}^{\mathrm{c}}$ offers a definition of the qnome as "the receiving [of] an Essential Attribute along with the One represented, the Self-Existing" (336

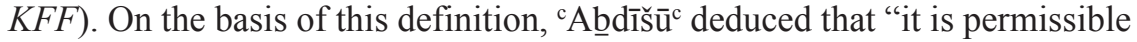
for us to say that the Creator (The Exalted One!) is One substance [and] Three Qnome" (337 KFF).

\subsection{Christ's revelation of the Trinity}

${ }^{\mathrm{c}} \mathrm{Ab} \mathrm{b} \overline{\mathrm{i}} \mathrm{s} \bar{u}^{\mathrm{c}}$ mentions that the doctrine of the Trinity as "the One substance and Three qnome" is the teaching of the Gospel ( ${ }^{i}$ inğ $\left.\bar{l} l\right)(337 \mathrm{KFF})$. He does not mention any quotation where he sees this teaching in the Gospel. It is more important for him to found the authority of this doctrine on the Gospel ( ${ }^{i n} \mathrm{~g} \breve{g} \bar{l} l$ ), which is considered a revealed Book also in Islam.

However, Christ proclaimed His Gospel, His new Law, and the Good News of salvation from death and sin in the future bliss in the Heavenly Kingdom (217-218 KFF), and in His Gospel He declared the Threeness and the Oneness of God (219 KFF), and He confirmed His message as true by his death, resurrection and ascension to His Father, the First Cause and condition of the Beginning and the End (220-221 KFF). He also confirmed the truth of the resurrection of the dead in the Last Day $(222 \mathrm{KFF})$ and the reward of happiness and bliss for good deeds and of punishment and painful torture for misdeeds $(224 K F F)$.

Furthermore, according to ${ }^{\mathrm{C}} \mathrm{A} \underline{\mathrm{b} d} \mathrm{~d} \overline{\mathrm{s}} \overline{\mathrm{u}}^{\mathrm{c}}$, Christ taught the sons of Adam that God is only one in his Essence, with no multiplication $(224 \mathrm{KFF})$, and that this Essence is substance because it subsists in itself $(225 K F F)$, but that this Essence has three Attributes: Necessity of Existence, the Wisdom, and the Life (226 $K F F$ ). These Attributes he called the qnome, expressing them as the Father and the Son and the Spirit of the Holiness $(227 K F F)$. Qnoma is partaking (taking as an eternal process without beginning and without end) in the Essence, along with being characterized by a property according to one of the three Attributes (228 KFF). God is only one because his Essence does not accept any accidents, partitions or divisions, and nothing is like him (229-232 $K F F)$. 


\section{Conclusion}

The Christian dogma of the Triune God has been, through the centuries, a problem for theological writers who have sought to explain this mystery. Christian theologians in the Muslim milieu were challenged to find a new way for explaining the Trinitarian doctrine and defending Christianity from the accusation that it is a polytheistic religion.

${ }^{c} A \underline{b} d \overline{1} \breve{s}^{c}{ }^{c}$ bar Brīhāa developed his own Trinitarian theology of attributes faithfully following the doctrine of the Church and using concepts he discovered in the writings of the Arabic Christian theologians who were his predecessors. ${ }^{37} \mathrm{He}$ has great confidence in the human intellect, so he based his exposition on logical reasoning. Firstly, he begins with the obvious fact which each intelligent human being accepts, that is, the existence of the world. Secondly, observing the nature of the world, he highlights its contingency and its incapability to exist of itself. Hence, the world is originated. Thirdly, the world as originated depends on its originator. So, the world has its originator. Finally, human intellect can conclude that the originator of the world is only one. $\mathrm{He}$ is God. ${ }^{c} \mathrm{~A} \underline{b} \mathrm{~d} \overline{1} \bar{s}^{\mathrm{u}} \mathrm{c}$ supports the Oneness of God with many divine attributes.

On the other hand, after having arrived at the oneness of God, ${ }^{\mathrm{c}} \mathrm{A} \underline{\mathrm{b}} \mathrm{d} \overline{\mathrm{s}} \mathrm{s} \overline{\mathrm{u}}^{\mathrm{c}}$ invites the reader to observe the pure Essence of God in Himself (Deus ad intram). Observation of God's Essence results in the proof that God, in His Essence, is the only One Essence (307-311 KFF). Considered in light of the three properties of this Essence, God is the Eternal in Essence (al-qadìm bi-d $\underline{d} \underline{d} \bar{a} t)$ (312 KFF), the Wise in Essence (al-hakim bi-d diat) (313-315 KFF) and the Living by Essence (al-hayy bi-d d $\underline{d} \bar{a} t)(316 \mathrm{KFF})$. So, the One and Unique Essence of God manifests itself by its own properties as the Father and the Son and the Holy Spirit (317-329 KFF). The Father is the Eternal One (al-qadìm) (317-318 KFF). The Son is Wise (al-hakim) (319-328 KFF) and the Wisdom $($ al-hikma) (326-328 KFF) "for Wisdom is generated from the Essence as the Wise eternally, outside of time, and without passivity" (327 KFF). The Holy Spirit is the Living-Subsisting (al-hayy al-qayyum), the Spirit (al-rūh), the True (al-haqq), the Holy One (al-quddīs) (329 KFF).

In conclusion, ${ }^{\mathrm{c}} \mathrm{A} \underline{\underline{b}} \mathrm{~d} \overline{1} \mathrm{~s}_{\mathrm{u}}^{\mathrm{c}}{ }^{\prime}$ 's intellectual reasoning expects his audience to weigh his logical arguments with fairness and respect. So, it can be seen that Christians cannot be polytheists, because the Christian Triune God is only One God.

\section{Bibliography}

${ }^{\mathrm{c} A}$ badī̌šù bar Brīhāā, Ktaba d-Marganitha (Mosul, 1924).

Ahlwardt, Wilhelm, Verzeichniss der arabischen Handschriften, Vol. IX (Berlin: Schade, 1889).

Aristotle, Metaphysics, translation, commentary and glossary by Hippocrates G. Apostle (Grinnell: Peripatetic Press, 1979).

Assemanus, Joseph Simonius, Bibliotheca Orientalis Clementino-Vaticana (Rome, 17191728).

Caspar, Robert, Théologie Musulmane. Tome II: Le credo (Rome: PISAI, 1999).

37

Haddad, La Trinité divine chez les théologi-

ens arabes (750-1050), pp. 208-233. 
Cheikho, Louis, Catalogue des manuscrits des auteurs arabes chrétiens (Beirut: Dar elMachreq, 2000).

Gardet, Louis, "Al-ªsmāo al-Husnā”, in: The Encyclopaedia of Islam, Vol. 1, ed. by B. Lewis, V. L. Ménage, Ch. Pellat and J. Schacht (Leiden, New York: Brill, 1986), pp. 714 717.

Gardet, Louis, "Illm al-Kalām", in: The Encyclopaedia of Islam, Vol. 3, ed. by B. Lewis, V. L. Ménage, Ch. Pellat and J. Schacht (Leiden, New York: Brill, 1986), pp. 1141-1150.

Hadad, Richard, La Trinité divine chez les théologiens arabes (750-1050) (Paris: Beauchesne, 1985).

Kawerau, Peter, "Ebed Jesus: Der Abschluß des antiochenischen Theologie", in: Kawerau, Peter, Christentum III: Das Christentum des Ostens (Stuttgart: Kohlhammer 1972), pp. 83-89.

Lane, Edward William, An Arabic-English Lexicon (Beirut: Libraire du Liban, 1968).

Mai, Angelo, Scriptorum veterum nova collectio, Vol. IV (Rome: Typis Collegii Urbani, 1831).

Paša, Željko, Kitāb farāoid al-fawā̄id fì ușūl ad-dīn wal-'aqā̄id - "Book of the Pearls of

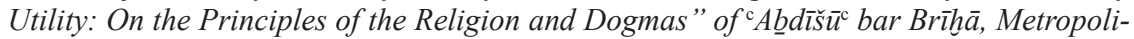
tan of Nisibis ( 1318), critical edition: Arabic text with translation, study and apparatus criticus (Rome: PIO, 2013).

Rahner, Karl, The Trinity, translated by Joseph Donceel (New York: Burns \& Oates, Continuum Imprint, 2001).

Sacerdote, Gustavo, I codici ebraici della Pia Casa de Neofiti in Roma (Rome, 1893).

Sachau, Eduard, Verzeichnis der syrischen Handschriften der Königlichen Bibliothek zu Berlin, Vol. 1 (Berlin, 1899).

Sadowski, Michal, The Trinitarian Analogies in the Christian Arab Apologetical Texts of the Middle and Near East during the Abbasid Period (750-1050) and Their Doctrinal Significance [Dissertation] (Rome: Pontificiam Univeristatem a S. Thoma Aq., 2012).

Samir, Samir Khalil, "Une profession de foi de cAbdišuc de Nisibe", in: Eulogema: Studies in Honor of Robert Taft, SJ, ed. by E. Carr, S. Parenti, A. A. Thiermeyer and E. Velkovska (Rome: Pontificio Ateneo S. Anselmo), pp. 427-451.

Studer, Basil, Dio salvatore nei Padri della chiesa: Trinità, cristologia, soteriologia, edited and translated into Italian by Daniele Gianotti (Rome: Borla, 1986).

Thomas Aquinas, Summa Theologiae, Vol. I, edition and study by Petri Caramello (Turin: Marietti, 1952-1956).

Troupeau, Gérard, Catalogue des manuscrits arabes. Première partie: Manuscrits chrétiens, Vol. I (Paris: Bibliothèque nationale, 1972).

Wehr, Hans, A Dictionary of Modern Written Arabic, ed. by J. Milton Cowan (Wiesbaden: Otto Harrassowitz, $\left.{ }^{3} 1979\right)$.

Wolfson, Harry Austryn, "The Muslim Attributes and the Christian Trinity", Harvard Theological Review, Vol. 49 (1956), No. 1, pp. 1-18.

Wolfson, Harry Austryn, The Philosophy of the Kalam (Cambridge, MA, London: Harvard University Press, 1976).

Wright, William, A Catalogue of Syriac Manuscripts Preserved in the Library of the University of Cambridge (Cambridge: The University Press, 1901).

Wright, William, A Grammar of the Arabic Language (Cambridge: Cambridge University Press, 1967). 


\section{Željko Paša}

\section{Pojam Božjeg jedinstva u djelu

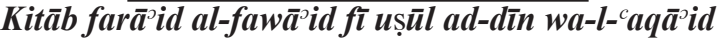 ${ }^{\mathrm{c}} \mathrm{Ab} \mathrm{b} \mathrm{I} \bar{s} \bar{u}^{\mathrm{C}} \mathrm{a}$ bar Brī̄hāa}

\section{Sažetak}

Dokazivanje Božje Jednosti i Trojstvenosti ${ }^{c} A b d \bar{l} \bar{s} \bar{u}^{c} a$ bar Brīhāa (umro 1318.) temelji se na logičkim argumentima. Kroz logičko zaključivanje ${ }^{c} A \underline{b} d \bar{i} \bar{s}_{\bar{u}}^{c}$ prvo iznosi tri principa religije: svijet je stvoren, svijet posjeduje svojeg Stvoritelja i Stvoritelj je Jedan i On posjeduje Tri Atributa. Promatrajući čistu Bit Božju, ${ }^{c} A \underline{b} d \bar{i} s \bar{u}^{c}$ zaključuje o nužnosti triju Atributa Bîti: nužnost Postojanja, Mudrosti i Života. Jedan Bog postoji u trima bitima (qnome): Otac, Sin i Duh Sveti.

Ključne riječi

Atributi, Bit, Trojstvo, Jednost, Trojstvenost, Qnoma

\section{Željko Paša \\ Begriff der Einheit Gottes

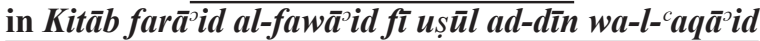 von ${ }^{\mathrm{c}} \mathbf{A} \underline{b}{ }^{\mathrm{i}} \overline{\mathbf{s}}_{\overline{\mathbf{u}}}^{\mathrm{c}}$ bar Brīhāā}

\section{Zusammenfassung}

Die Demonstration der Einheit und Dreifaltigkeit Gottes von ${ }^{c} A \underline{b} d \bar{l} \bar{s} \bar{u}^{c}$ bar Brīha (gestorben 1318) stützt sich auf logische Argumente. Anhand logischer Argumentation führt er als Erstes drei Prinzipien der Religion an: die Welt wurde erschaffen, die Welt hat den Erschaffer, und dieser Erschaffer ist der Eine und Er besitzt Drei Attribute. Indem er das reine Wesen Gottes betrachtet, leitet ${ }^{c} A \underline{b} d \bar{l} \bar{s} \bar{u}^{c}$ daraus die Notwendigkeit der drei Attribute des Wesens ab: die Notwendigkeit der Existenz, der Weisheit und des Lebens. Der Eine Gott existiert in drei Wesen (qnome): der Vater, der Sohn und der Heilige Geist.

\section{Schlüsselwörter}

Attribute, Wesen, Trinität, Einheit, Dreifaltigkeit, Qnoma

\section{Željko Paša}

\section{Le concept de l'unité de Dieu dans le}

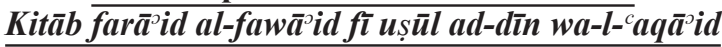 par ${ }^{\mathrm{c}} \mathbf{A} \underline{b}$ dīšs̆ $\overline{\mathbf{c}}^{\mathrm{c}}$ bar Brīhāā}

\section{Résumé}

La démonstration de l'unicité et de la trinité de Dieu par ${ }^{c} A \underline{b} d \bar{l} \breve{s} \bar{u}^{c}$ bar Brīhāa (mort en 1318) se fonde sur des arguments logiques. Il met en évidence, à travers un raisonnement logique, trois Principes Religieux : le monde est une création, le monde possède son Créateur, le Créateur est Un et est doté de Trois Attributs. En observant l'essence pure de Dieu, 'cAbdī̌š $\bar{u}^{c}$ déduit la nécessité des trois Attributs de l'Essence: la nécessité de l'Existence, la Sagesse et la Vie. Un seul Dieu existe dans les trois essences (qnome): le Père, le Fils et le Saint-Esprit.

Mots-clés

Attributs, Essence, Trinité, Unicité, Triade, Qnoma 